УДК 641.78:664

DOI https://doi.org/10.15673/swonaft.v85i1.2064

\title{
ЕКСПЕРИМЕНТАЛЬНІ ДОСЛІДЖЕННЯ КІНЕТИКИ ТЕМПЕРАТУРИ ФІЛЬТРАЦІЙНОГО СУШІННЯ ПІД ДІЄЮ ПІДВИЩЕНОГО ТИСКУ
}

\author{
Потапов В.О., професор, д.т.н., Якушенко Є.М., доцент, к.т.н., \\ Гриценко О.Ю., інженер \\ Харківський Державний Університет Харчування та Торгівлі, м. Харків
}

\begin{abstract}
Проведено експериментальні дослідження кінетики температури під час фільтраційного сушіння вологого матеріалу у випарно-конденсаиійному модулі (ВКМ) під дією підвищеного тиску, щзо створюються зовнішнім компресором. При иъьому компресор використовуються для одночасного нагрівання сушильного агенту та його фільтрації через шар матеріалу у ВКМ. Досліджено вплив тиску від 0,2 до 0,6 МПа на кінетику температури та тепловий к.к.д. процесу сушіння. Теоретично доведено та експериментально підтверджено, що тепловий к.к.д. фільтраційного сушіння в сушариі з ВКМ на $12 \ldots 15$ \% вище ніж в конвекиійних фільтрачійних сушарках в діапазоні температур $55 \ldots 90{ }^{\circ}$ C. Показано, що за умов надлишкового тиску існує постійний градієнт температур за шаром матеріалу та довжиною ВКМ на відміну від фільтраційного сушіння за атмосферного тиску.
\end{abstract}

Ключові слова: фільтраційне сушіння, підвищений тиск, кінетика температури, політропні процеси, енергоефективність.

Вступ. В сучасних умовах при швидкому подорожчанні енергоносіїв, особливо актуальною стає проблема енергозбереження у виробничо-господарської діяльності підприємств. Одним з найбільш енергоємних процесів є теплове сушіння. Як відомо, корисна енергія, що витрачається на випаровування вологи в конвекційних сушарках, за різними розрахунками складає всього 40...50 \% [1]. Питомі енерговитрати конвекційних сушарок, які використовуються на підприємствах досягають 8 МДж/кг видаленої вологи, що практично втричі більше фізично необхідного мінімуму [2]. Крім того, викиди відпрацьованого сушильного агента 3 високим тепловмістом збільшують теплове забруднення оточуючого середовища. Відзначені проблеми $є$ найбільш актуальними для вирішення на сучасному етапі розвитку теорії та техніки сушіння. Тому створення нових технологій, контурентноспроможного промислового устаткування і технологічних ліній 3 урахуванням вимог до раціонального використання енергії та захисту довкілля є першочерговою задачею.

3 практичного досвіду відомо, що більшу частину втрат енергії при тепловому сушіння припадає на викиди з відпрацьованим сушильним агентом, тому сучасні тенденції розвитку техніки сушіння спрямовані в першу чергу на скорочення саме цієї статті енерговитрат [3]. До таких перспективних способів сушіння слід віднести застосування теплових насосів, сушіння із радіаційним підведенням теплоти (НВЧ та ІЧ сушіння), комбіновані способи сушіння, які використовують адресну доставку енергії до об'єму матеріалу [4]. Саме до такого способу сушіння слід відносити фільтраційне сушіння, під час якого сушильний агент фільтрується через шар дисперсного вологого матеріалу, що дозволяє, по перше, видаляти частину вільної вологи без перетворення іiі в пару, а, по друге, суттєво збільшити коефіцієнти тепло-масообміну та скоротити тривалість сушіння, а відповідно і питомі енерговитрати [5].

Подальшим розвитком способу фільтраційного сушіння є спосіб сушіння під дією підвищеного тиску [6], який має наступні переваги: нагрівання та переміщення сушильного агента здійснюється одним пристроєм - компресором, в результаті досягається повне використання ентальпії сушильного агенту, яка витрачається не тільки на нагрівання та випаровування, але й на здійснення роботи по подоланню гідродинамічного опору шару матеріалу. Як наслідок цього температура на виході із сушарки може бути нижче температури адіабатного насичення і теоретично навіть нижче температури оточуючого середовища, що призводе до повної відсутності теплових втрат з відпрацьованим сушильним агентом.

Раніше нами було досліджено особливості кінетики вологовмісту в процесі сушіння під дією надлишкового тиску [7], де було виявлено основні закономірності цього процесу [8]. У зв'язку з цим метою даної роботи є експериментальне дослідження кінетики температури фільтраційного сушіння під дією підвищеного тиску, оскільки саме температура відпрацьованого сушильного агента визначає енергоефективність сушарки, а температура матеріалу безпосередньо впливає на якісні показники матеріалу, що зневоднюється.

Матеріали та методи досліджень. Для дослідження кінетики процесу фільтраційного сушіння під дією підвищеного тиску використовувалась експериментальна установка, яка зображена на рис .1. 


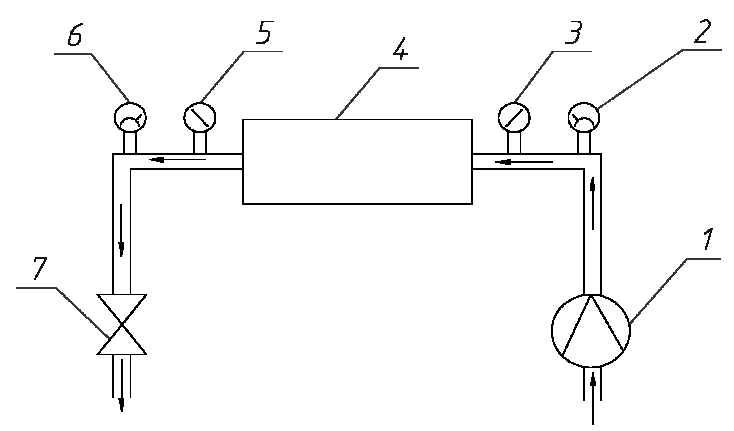

1 -компресор; 2,6 - датчики температури; 3,5 - датчики тиску; 4-випарно-конденсаційний модуль; 7 - дросель

\section{Рис. 1 - Схема експериментальної установки}

Температури у випарно-конденсаційному модулі та у шарі матеріалу вимірювались термопарами. Схема розміщення термопар представлена на рис. 2.

Експерименти проводились на моделі колоїдного капілярно пористого тіла у якості якого була обрана попередньо підготовлена дерев'яна тирса.

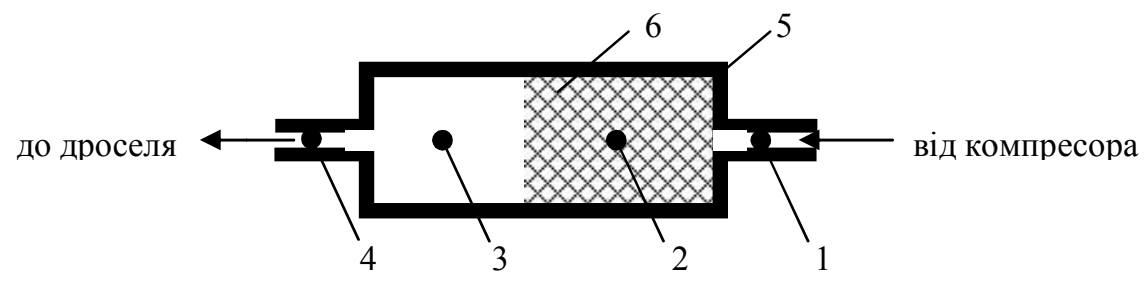

1,2,3,4 - термопари; 5 - випарно-конденсаційний модуль; 6 - шар матеріалу, щзо висущується

\section{Рис. 2 - Схема розміщення термопар у ВКМ}

Результати досліджень. На рис. 3 наведено осереднені температури сушильного агенту за весь період сушіння під тиском.

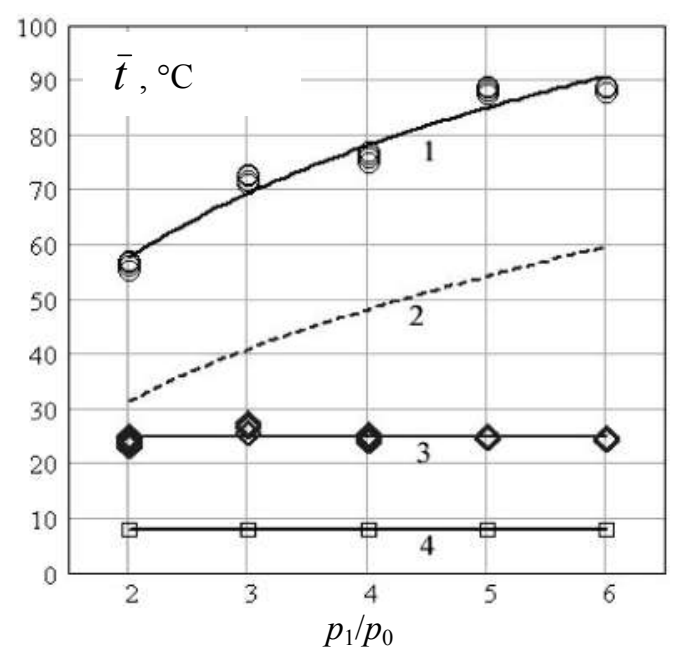

1 - температура сушильного агенту на вході у ВКМ; 2 - розрахункова температура адіабатного насичення сушильного агенту на виході із ВKM; 3 - температура сушильного агенту на виході із BKM; 4 температура сушильного агенту на вході в компресор

\section{Рис. 3 - Середні температури сушильного агенту за весь період сушіння}

Температура на виході із сушарки виявляється меншою ніж температура адіабатного насичення сушильного агенту при поточних значеннях температури на тиску на виході із сушарки. На рис. 3 температура адіабатного насичення сушильного агенту $\left(t_{a d}\right)$ розрахована за умов постійної ентальпії сушильного агенту у процесі сушіння (втрати через теплоізоляцію ВКМ відсутні) для заданої температура на вході $\left(t_{1}\right)$ та тисків на вході $\left(p_{1}\right)$ та виході $\left(p_{2}\right)$.

Ці експериментальні данні підтверджують принципову особливість процесу фільтраційного сушіння під тиском: сушильний агент повністю насичується вологою з матеріалу, а за рахунок виконання механічної 
роботи по переміщенню паро-рідинної суміші крізь шар матеріалу зменшує свою температуру нижче температури адіабатного насичення.

Низька температура на виході із сушарки означає, що зменшуються втрати теплоти з відпрацьованим сушильним агентом. Це призводить до підвищення енергоефективності процесу сушіння. Розрахуємо тепло-

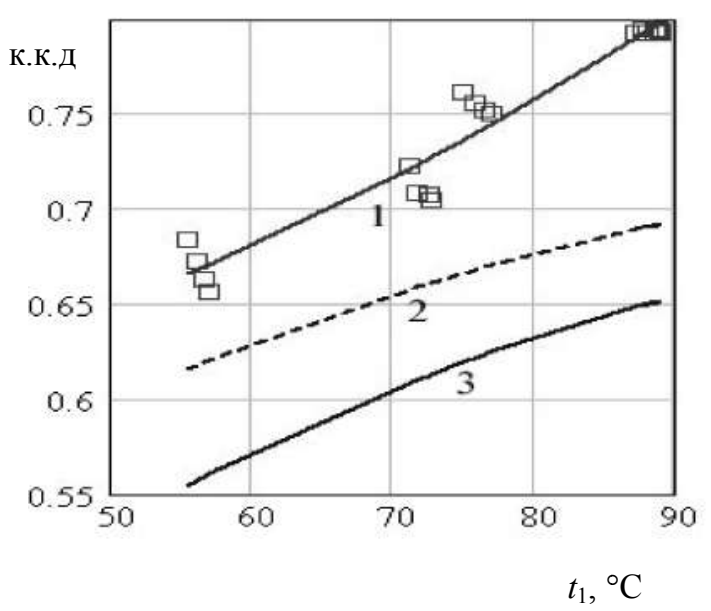

1 - фільтраційне сушіння під тиском; 2 розрахунковий к.к.д. конвекиійного сушіння за нормального тиску ф2 $=100 \%$; 3 розрахунковий к.к.д. конвекиійного сушіння за нормального тиску $\varphi_{2}=60 \%$

Рис. 4 - Тепловий к.к.д. процесу фільтраційного сушіння під тиском та конвекційного сушіння

$12 \ldots 15 \%$ вище ніж в конвекційних сушарках.

На рисунках 5, 6 наведено результати з кінетики температур під час фільтраційного сушіння під тиском для різної товщини шару $\left(l_{\mathrm{M}}\right)$ та тисків.

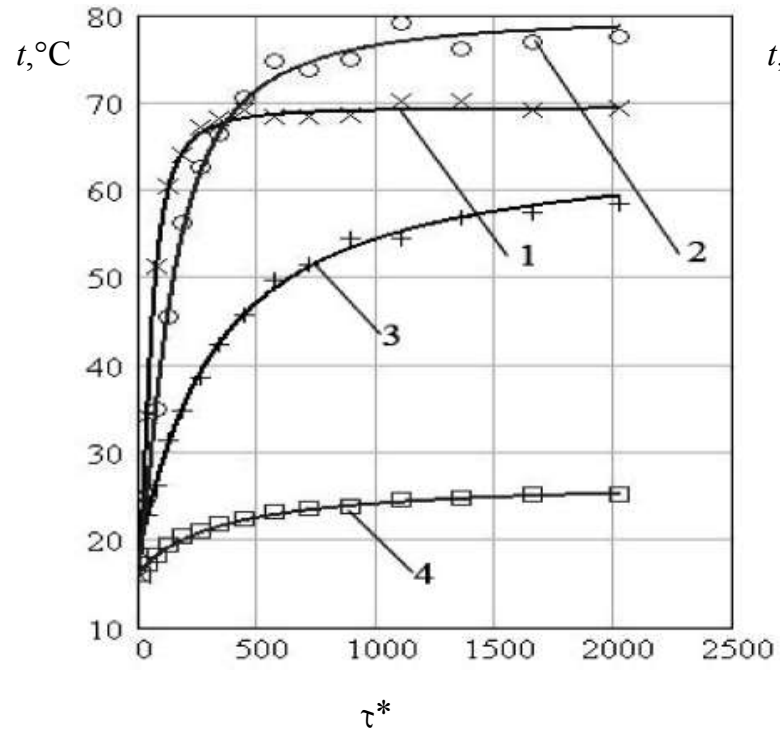

1 - на вході в ВКМ; 2 - середня температура в uарі; 3 - на виході з шару; 4 - на виході з ВKM

\section{Рис. 5 - Кінетика температури сушіння під} тиском $p_{1}=0,2$ МПа, $l_{\mathrm{M}}=0,06 \mathrm{м}$ вий к.к.д. сушарки за відомою формулою

$$
\text { к.к.д. }=\frac{t_{1}-t_{2}}{t_{1}-t_{0}}
$$

Для конвекційного сушіння температура на виході із сушарки $t_{2} \geq t_{a d}$, а для фільтраційного сушіння під тиском $t_{2}$ $<t_{a d}$, тому тепловий к.к.д. сушарки в цьому випадку буде вищий.

На рис. 4 наведено порівняння експериментальних даних про к.к.д. процесу фільтраційного сушіння під тиском та конвекційного сушіння за нормального тиску.

Тепловий к.к.д. конвекційного сушіння розраховувався за умов ізоентальпійного процесу в сушарці $\left(t_{2} \geq t_{a d}\right)$ за тих же значень температур $t_{1}, t_{0}$, що і для фільтраційної сушари під тиском.

Лінія 2 на рисунку 4 відповідає теоретично максимальному к.к.д. конвекційної сушарки, коли вологість сушильного агенту на виході $\varphi_{2}=100 \%$. Реально на практиці $\varphi_{2}=60 \ldots 80 \%$, бо інакше буде спостерігатись конденсація вологи із повітря на матеріалі, що висушується. Для фільтраційного сушіння, як вже зазначалось, це не має значення, бо волога, що конденсується в шарі матеріалу, вилучається з нього під дією підвищеного тиску.

Як свідчать наведені данні, тепловий к.к.д. фільтраційного сушіння в експериментальній сушарці на 
частково заповнений). Температурні криві з позначкою 2 вимірювались в шарі матеріалу. Залежно від товщини шару всередині нього розміщувалось від 1 до 3 термопар і показання з них осереднювались за об'ємом шару.

Особливістю кінетики температури фільтраційного сушіння під тиском є те, що від початку до кінця процесу сушіння існує градієнт температур за шаром матеріалу та довжиною ВКМ на відміну від конвекційного сушіння, де висушений матеріал наприкінці процесу має температуру сушильного агенту. Цей факт пояснюється особливістю гідродинаміки газового потоку під тиском. При відсутності теплообміну $з$ оточуючим середовищем, та без здійснення роботи газом температура сушильного агенту буде зменшуватись за напрямком руху, якщо швидкість потоку збільшується і навпаки. Так у пустому ВКМ при вході стиснутого після компресора газу відбувається його миттєве розширення (діаметр ВКМ 160 мМ, а діаметр трубопроводу 10 мм), тому швидкість потоку зменшується, а його температура зростає. Навпаки при виході з ВКМ у трубопровід газ пришвидшується а температура його зменшується.

Зазначимо, що цей перепад температур між входом та виходом сушарки не є наслідком втрат теплоти, а є результатом перетворення кінетичної енергії потоку газу. Саме тому, як зазначалось вище, забезпечується низька температура на дроселі після ВКМ, що призводить до підвищення к.к.д. сушарки..

Наведені особливості пояснюються теорією газодинаміки. Згідно рівняння тепловмісту газового потоку у відсутності впливу сили тяжіння

$$
Q-A=\frac{\omega_{2}{ }^{2}-\omega_{1}{ }^{2}}{2}+c_{p}\left(t_{2}-t_{1}\right),
$$

де $Q$ - питома теплова енергія, що підводиться до газового потоку на ділянці 1-2, Дж/кг; $A$ - питома технічна робота потоку, Дж/кг; $\omega_{1}, \omega_{2}$ - швидкість потоку на вході та вході з ділянки 1-2, м/с; питома теплоємність газу, Дж/(кг·К); $t_{1}, t_{2}$ - температура газового потоку вході та вході з ділянки 1-2/.

Звідки отримуємо, що різниця температур сушильного агенту під тиском залежить від співвідношення швидкостей потоку на конкретній ділянці ВКМ та термодинамічного процесу, який відбувається на цій ділянці

$$
t_{1}-t_{2}=\frac{1}{c_{p}}\left(\frac{\omega_{2}^{2}-\omega_{1}^{2}}{2}-Q+A\right) .
$$

3 іншого боку з узагальненого рівняння Бернуллі у відсутності впливу сили тяжіння питома технічна робота потоку дорівнює

$$
-A=\frac{\omega_{2}{ }^{2}-\omega_{1}{ }^{2}}{2}+\int_{1}^{2} \frac{1}{\rho_{2}} d p+A_{m p},
$$

де $A_{m p}$ - питома робота сил тертя в потоці, Дж/кг; $\rho_{2}$ - густина газу.

3 урахуванням (3) та (4) у випадку політропного процесу отримуємо наступну формулу, яка визначає зміну температури сушильного агенту в процесі фільтраційного сушіння під тиском

$$
t_{2}-t_{1}=\frac{1}{c_{p}}\left\{\frac{n}{n-1} \frac{p_{1}}{\rho_{a 1}}\left[\left(\frac{p_{2}}{p_{1}}\right)^{\frac{n-1}{n}}-1\right]+Q+A_{m p}\right\}
$$

де $\rho_{a 1}-$ густина сушильного агенту, яка відповідає тиску $p_{1}$, кг $/ \mathrm{M}^{3}$.

Згідно цієї формулі, за умови відсутності втрат теплоти $(Q)$ та втрат на тертя $\left(A_{m p}\right)$, зменшення тиску $\left(p_{2}\right.$ $\left.<p_{1}\right)$ від входу в шар матеріалу до виходу із ВКМ повинно зменшувати температуру сушильного агенту у напрямку його руху $\left(t_{2}<t_{1}\right)$. Тому для тонкого шару матеріалу, коли його гідродинамічний опір майже відсутній, середня температура шару матеріалу буде меншою за температури на вході в шар. Оскільки 3 підвищенням тиску зростає робота сил тертя, яку здійснює сушильний агент по переміщенню паро-рідинної суміші через ВКМ, то при більшому тиску (0,6 МПа) температура матеріалу менша ніж при тиску 0,3 МПа.

Інша закономірність спостерігається при збільшенні товщини шару. Як свідчать данні на рис. 5 та 6 середня температура шару матеріалу стає більшою за температури на вході у ВКМ. Це пояснюється рівнянням (5), згідно якого при збільшенні роботи сил тертя різниця температур на вході в шар та в самому шарі буде позитивною, якщо величина $A_{m p}$ буде більшою, ніж перші два члени правої частини рівняння.

Це пояснюється наступним рівнянням для питомої сили тертя газового потоку в каналі

$$
A_{m p}=\int_{x_{1}}^{x_{2}} \varsigma \frac{\omega^{2}}{2} \frac{d x}{D},
$$

де $\zeta$ - коефіцієнт тертя; $D$ - еквівалентний діаметр каналу, м. 
Оскільки швидкість потоку залежить від тиску на ділянці 1-2 (рис.2), як і коефіцієнт тертя, то питома робота сил тертя буде збільшуватися зі збільшенням тиску та відношенням товщини шару до діаметру фільтраційних каналів у матеріалі. Саме тому зі збільшенням товщини шару та тиску спостерігається збільшення температури матеріалу під час фільтраційного сушіння під тиском.

Таким чином встановлені особливості кінетики температури в процесі фільтраційного сушіння під тиском цілком пояснюються теорією газодинаміки. Ці особливості слід враховувати при проектуванні фільтраційних сушарок під тиском, оскільки значення температур за шаром матеріалу безпосередньо пов'язані як 3 тиском на виході компресора, так із гідравлічним опором шару. Зважаючи на це слід визначати раціональну товщину шару матеріалу, оскільки існує обмеження за максимальним гідродинамічним опором шару, яке пов'язано з тим, що регулювання температури сушильного агента здійснюється регулюванням тиску зовнішнього компресора.

Висновки. Досліджено кінетику температури під час фільтраційного сушіння під дією підвищеного тиску та отримано експериментальні данні про температуру в шарі матеріалу та у випарно-конденсаційному модулі на ділянці від компресора до виходу із сушарки.

Виявлено особливості впливу тиску від 0,2 до 0,6 МПа на кінетику температури та тепловий к.к.д. процесу сушіння. Теоретично доведено та експериментально підтверджено, що тепловий к.к.д. фільтраційного сушіння в сушарці з випарно-конденсаційним модулем на $12 \ldots 15 \%$ вище ніж в конвекційних сушарках в діапазоні температур $55 \ldots 90^{\circ} \mathrm{C}$.

Виявлено, що за умов надлишкового тиску існує постійний градієнт температур за шаром матеріалу та довжиною модуля на відміну від фільтраційного сушіння за атмосферного тиску. Цей градієнт виникає внаслідок політропного процесу у ВКМ з матеріалом за наявності теплообміну з оточуючим середовищем та сил тертя. При цьому цей градієнт температур не $\epsilon$ наслідком втрат теплоти, а $є$ результатом перетворення кінетичної енергії потоку газу, що призводить до зниження втрат теплоти з відпрацьованим сушильним агентом.

Отримані особливості кінетики температури слід враховувати при проектуванні фільтраційних сушарок під тиском.

\title{
References
}

1. Denisyuk, S.P. (2013). Formuvannya polityky pidvyshchennya enerhetychnoyi efektyvnosti - suchasni vyklyky ta yevropeys'ki oriyentyry [Formation of energy efficiency policy - modern challenges and European guidelines]. Energy: economics, technologies, ecology, 2, 7-22 [in Ukrainian].

2. Bevz, S.M., Bondarenko, B.I., Denisyuk, S.P. (2007). Enerhoefektyvnist' ta vidnovlyuvani dzherela enerhiyi [Energy efficiency and renewable energy sources]. In A.K. Shidlovsky (Ed.), Kyiv: Ukrainian encyclopedic knowledge [in Ukrainian].

3. Snezhkin, Y.F. (2009). Puty yntensyfykatsyy protsessov sushky [Ways to intensify drying processes]. Industrial heat engineering, 31(7), 89-90 [in Ukrainian].

4. Burdo, O.G. (2010). Evolyutsiya sushil'nykh ustanovok [Evolution of dryers]. Odessa: POLYGRAPH, 368 [in Ukrainian].

5. Atamanyuk, V.M., Khanyk, Y.M. (2007). Klasyfikatsiya dyspersnykh materialiv, yak ob”yektiv sushinnya fil'tratsiynym metodom [Classification of dispersed materials as objects of drying by the filtration method]. Chemical industry of Ukraine. 3, 37-45 [in Ukrainian].

6. Potapov, V.O., Petrenko, O.V., Gritsenko, O.Y. (2016). Ukr. Patent No 108135 Method of drying food products in the heat and mass exchange module under the action of high pressure [in Ukrainian].

7. Potapov, V., Hrytsenko, O. (2019). Theoretical analysis of the energy efficiency of the filtration drying at high pressure. Chemical Technology and Engineering: 2 International Scientific Conference (pp. 83-86). Lviv: LPAU [in Ukrainian].

8. Potapov, V.O., Gritsenko, O.Y. (2019). Eksperymental'ni doslidzhennya kinetyky fil'tratsiynoho sushinnya pid diyeyu pidvyshchenoho tysku na modeli koloyidnoho kapilyarno porystoho tila [Experimental studies of filtration drying kinetics under the action of high pressure on a model of a colloidal capillary porous body]. Proceedings of the VII International Scientific and Practical Conference "Innovative Energy Technologies" (pp. 185-188). Odessa, ONAHT [in Ukrainian].

\section{EXPERIMENTAL STUDIES OF TEMPERATURE KINETICS DURING FILTRATION DRYING UNDER THE ACTION OF HIGH PRESSURE}

\author{
Potapov V.O., professor, Dr. Sci. Tech., Yakushenko E.M., Associated professor, PhD, \\ Hrytsenko O.Y., engineer \\ Kharkiv State University of Food Technology and Trade, Kharkiv, Ukraine
}

One of the most energy-intensive processes is thermal drying. It is known that the useful energy expended on the 
evaporation of moisture in convection dryers, according to various calculations, is only $40 \ldots 50 \%$. The specific energy consumption of convection dryers used in enterprises reaches $8 \mathrm{MJ} / \mathrm{kg}$ of removed moisture, which is almost three times more than the physically required minimum. In addition, emissions of spent drying agent with a high heat content increase the thermal pollution of the environment.

One way to solve this problem is filtration drying under high pressure. This method of drying has the following advantages: heating and moving the drying agent is carried out by one device - a compressor, resulting in full use of the enthalpy of the drying agent, which is spent not only on heating and evaporation, but also on overcoming hydrodynamic resistance. As a consequence, the temperature at the outlet of the dryer can be lower than the adiabatic saturation temperature and theoretically even lower than the ambient temperature, which leads to the complete absence of heat loss with the spent drying agent.

Experimental studies of temperature kinetics during filtration drying under high pressure of wet material in the evaporation-condensation module (VCM) under the action of excess pressure generated by an external compressor have been carried out. The influence of pressure from 0.1 to $0.6 \mathrm{MPa}$ on temperature kinetics and thermal efficiency of drying process was investigated. It is theoretically proved and experimentally confirmed that the thermal efficiency filtration drying in a dryer with VCM $12 \ldots 15 \%$ higher than in convection filtration dryers in the temperature range $55 \ldots 90{ }^{\circ} \mathrm{C}$. It is shown that under conditions of excess pressure there is a constant temperature gradient over the material layer and the length of the VCM in contrast to filtration drying at atmospheric pressure. This gradient occurs due to the polytropic process in VCM with the material in the presence of heat exchange with the environment and friction forces. In this case, this temperature gradient is not a consequence of heat loss, but is the result of the conversion of the kinetic energy of the gas flow, which leads to a decrease in heat loss with the spent drying agent.

Keywords: filtration drying, overpressure, temperature kinetics, polytropic processes, energy efficiency.

\section{Список використаної літератури}

1. Денисюк С.П. Формування політики підвищення енергетичної ефективності - сучасні виклики та європейські орієнтири. Енергетика: економіка, технології, екологія, 2013. № 2. С. 7-22.

2. Енергоефективність та відновлювані джерела енергії / Під заг. ред. А.К. Шидловського; Авт.: Бевз С.М., Бондаренко Б.І., Денисюк С.П. та інш. К.: Українські енциклопедичні знання, 2007. 500 с.

3. Снежкин Ю.Ф. Пути интенсификации процессов сушки. Промышиленная теплотехника, 2009. Т. 31, № 7. С.89-90.

4. Бурдо О.Г. Эволюция сушильных установок. Одесса: Полиграф, 2010. 368 с.

5. Атаманюк В. М., Ханик Я. М. Класифікація дисперсних матеріалів, як об’єктів сушіння фільтраційним методом. Хімічна промисловість України, 2007. № 3. С. 37-45.

6. Патент на корисну модель № 108135 «Спосіб сушіння харчових продуктів в тепломасообмінному модулі під дією підвищеного тиску» (автори: Потапов В.О., Петренко О.В., Гриценко О.Ю.); Опубліковано 11.07.2016, бюл. № 13/2016, 4.c

7. Potapov V., Hrytsenko O. Theoretical analysis of the energy efficiency of the filtration drying at the high pressure. Chemical Technology and Engineering: 2 International Scientific Conference (24-28.06. 2019). Львів. ЛПАУ.2019. С.83-86.

8. Потапов В.О., Гриценко О.Ю. Експериментальні дослідження кінетики фільтраційного сушіння під дією підвищеного тиску на моделі колоїдного капілярно пористого тіла. Збірник наукових праць VII міжнародної науково-практичної конференції «Інноваційні енерготехнології», 9-13 вересня 2019. Одеca, OHAXT, 2019, C.185-188.

Отримано в редакцію 22.03 .2021

Received 22.03.2021

Прийнято до друку 23.06.2021

Approved 23.06.2021 